\title{
IN VITRO TESTING OF GENTAMICIN-VANCOMYCIN LOADED BONE CEMENT TO PREVENT PROSTHETIC JOINT INFECTION
}

\author{
Jiří Gallo**, Milan Kolář ${ }^{\mathrm{b}}$, Anthony V. Florschütz ${ }^{\mathrm{c}}$, Radek Novotnýd, Roman Pantůčeke, \\ Michaela Kesselováb
}

a Department of Orthopaedics, Palacký University, Teaching Hospital, Olomouc, Czech Republic,

b Department of Microbiology, Palacký University, Olomouc, Czech Republic

c Currently affiliated with the Department of Orthopaedics, Mayo Clinic, Rochester, MN, USA

${ }^{d}$ Department of Microscopic Methods, Palacký University, Olomouc, Czech Republic

e Department of Genetics and Molecular Biology, Faculty of Science, Masaryk University, Brno, Czech Republic e-mail:jiri.gallo@volny.cz

Received: April 26, 2005; Accepted: May 28, 2005

Key words: Prosthetic joint infection/Polymethylmethacrylate/Antibiotic loaded cement/Vancomycin/Gentamicin/ Staphylococcus aureus/Staphylococcus epidermidis

Sepsis is a greatly feared complication of total joint arthroplasty. One key question is how to prevent perioperative bacterial adherence, and therefore the potential for infectious complications. The objective of our study was to appraise the emerging capacity of staphylococcal survival on prosthetic materials and to analyze the in vitro effects of gentamicin and vancomycin loaded polymethylmethacrylate (PMMA) cement on bacterial adherence and growth. Hospital acquired staphylococcal strains were systematically inoculated on four orthopedic materials (ultrahigh molecular weight polyethylene, PMMA without antibiotic, commercially produced PMMA loaded with gentamicin, and manually mixed PMMA loaded with gentamicin and vancomycin). Staphylococci were identified using culture and biochemical tests. The inoculated material was allowed to incubate in a liquid broth growth media and subsequently prepared for scanning electron microscopy and bacterial growth quantification. Materials without antibiotics showed evidence of staphylococcal growth. PMMA loaded with only gentamicin grew methicillin-resistant Staphylococcus aureus. Gentamicin-vancomycin loaded PMMA completely inhibited any bacterial growth.

Low-dose gentamicin-vancomycin loaded PMMA prevents staphylococcal colonization better than commercially manufactured PMMA loaded with gentamicin. We recommend this combination in high-risk procedures and revision surgeries requiring bone cement.

\section{INTRODUCTION}

Total hip and knee arthroplasties are among to the most effective, routine, and successful orthopaedic procedures today ${ }^{9,28}$. Nevertheless, complications do arise. These can result in prosthetic failure and poor long-term patient outcomes. Among possible complications, prosthetic joint infection (PJI) is one of the most difficult and serious conditions to diagnose and manage ${ }^{11,14}$. Between $1 \%$ and $5 \%$ of all primary total hip and knee arthroplasties are complicated by PJI, and the percentage is even higher after revision procedures ${ }^{22}$.

The majority of PJIs are biofilm-dependent, but certain highly virulent bacterial strains do not rely on this strategy and can be detected very early in the course of infection ${ }^{22}$. In both acute and chronic PJI, Staphylococcus aureus and coagulase-negative staphylococci are regularly isolated. Additionally, there are also some inconspicuous $S$. aureus strains (the so-called "small colony variants") that can present a complex diagnostic puzzle, mimicking other microorganisms with low virulence like Staphylococcus epidermidis ${ }^{26}$.
Two general schemes of PJI pathogenesis are generally accepted. The first is postoperative colonization of the joint space (hematogenous type) that is more typical for late infections. The second arises via intraoperative colonization (surgical type) that usually manifests days to months postoperatively ${ }^{21}$. If bacteria fail to settle in the joint during this time, the risk of joint sepsis rapidly decreases $^{8}$. From both scenarios it is clear that active prevention of intraoperative and postoperative bacterial colonization is strongly worth the effort.

Several approaches have been proposed to prevent and treat early surgery-related bacterial colonization of prosthetic surfaces. One is the antimicrobial approach that relies on the local release of loaded antibiotics from polymethylmethacrylate (PMMA) bone cement and maintains a sufficient bactericidal concentration in the immediate vicinity for a duration of time after polymerization ${ }^{15,20,27}$. Our current study examines the ability of gentamicin-vancomycin loaded PMMA to prevent growth of staphylococci in vitro. 


\section{MATERIALS AND METHODS}

Four different biomaterial formulations were prepared to test the ability of staphylococcal growth. The first material (I) manually prepared from original ultrahigh molecular weight polyethylene (UHMWPE) cups (Chirulen, Aesculap, B-Braun, Germany) to obtain slides approximately 1 by $1 \mathrm{~cm}$. The second tested material (II) was PMMA without antibiotics $\left(\right.$ Palamed $^{\circledR}, 40 \mathrm{~g}$, Biomet Merck $\mathrm{GmbH}, \mathrm{CH}-6460$, Altdorf) that was prepared to have a similar shape and size as the UHMWPE slides and served as a control. The third (III) and fourth (IV) materials were prepared from Palamed ${ }^{\circledR}$ G (40 g, Biomet Merck $\mathrm{GmbH}, \mathrm{CH}-3216$, Ried b.Kerzers) with the same dimensions as mentioned above. In addition, the fourth sample was loaded with $1 \mathrm{~g}$ of vancomycin (Eli Lilly) per batch of Palamed bone cement. The polymer and vancomycin in crystalline form were hand mixed before the monomer was added. The gentamicin-vancomycin antibiotic combination was selected because of the routine high-dose application at our clinic in therapeutic interventions as well as the proven effectiveness from the current literature ${ }^{4}$.

\section{Staphylococcal Isolation and Identification}

Four staphylococcal strains were isolated from the patients hospitalized at the Teaching Hospital in Olomouc, Czech Republic (Table 1). The identification of staphylococci was performed by the BBL Crystal Gram-Positive ID Kit (Becton Dickinson Int.), a Crystal Panel Viewer (Becton Dickinson Int.), and the computer identification system BBL CrystalMIND V5.00c (Becton Dickinson Int.).

\section{Antibiotic Susceptibility Testing}

Antibiotic susceptibility was established for each staphylococcal strain via a standard dilution micromethod ${ }^{1}$. S. aureus reference strains (ATCC 29213 and ATCC 25923 ) were used for protocol quality control. The isolates were additionally tested for the presence of penicillin binding protein $2 \mathrm{a}$ (PBP2a) by a latex agglutination test (MRSA-Screen test, Denka Seiken Co.).

\section{Biofilm Detection}

The ability of staphylococci to organize into biofilms was demonstrated by a modified test using crystal violet stain ${ }^{6}$. Isolated staphylococci were cultivated for $24 \mathrm{~h}$ in Brain Heart Infusion (BHI, Oxoid) broth containing $0.25 \%$ glucose in microtitration plate wells. After incubation, the BHI broth containing free planktonic cells was drained. Each well was then stained with $1 \%$ crystal violet, rinsed with distilled water, dried, and visually evaluated for the presence of biofilm.

\section{Biomaterial Bacterial Inoculation and Incubation}

Each prepared orthopaedic sample was tested against each of the four bacterial isolates (Table 1) in quadruplicate (four identical samples per single material per bacterial isolate). Samples were separately and aseptically placed in a test tube containing $10 \mathrm{ml}$ of BHI broth and inoculated with five colonies of a given staphylococcal isolate. The samples were then incubated under aerobic conditions for $48 \mathrm{~h}$ at $37^{\circ} \mathrm{C}$. Evidence of staphylococcal growth was evaluated at 24 and $48 \mathrm{~h}$ according to gross visual media opacity and by bacterial cultivation on blood agar (Oxoid) for $24 \mathrm{~h}$ at $37^{\circ} \mathrm{C}$ under aerobic conditions. The cultivated strains were compared with the original inoculating strains using the methods previously mentioned and DNA analysis.

After $48 \mathrm{~h}$ of incubation, the tested materials were removed from their respective test tubes and individually preserved in a dry test tube under sterile conditions for 7 days at room temperature. Following this period, the materials were once again placed in a test tube with $10 \mathrm{ml}$ of BHI broth and incubated for $48 \mathrm{~h}$ at $37^{\circ} \mathrm{C}$. After 24 and $48 \mathrm{~h}$, cultivated strains were evaluated using the same methods as before.

\section{DNA Analysis}

Staphylococci were also characterized by isolated restriction splitting DNA analysis using Sma I restriction endonucleases (Roche Diagnostics) and pulse field gel electrophoresis (PFGE) splitting. Restriction maps for single isolates were subsequently determined and used for strain comparison.

Isolation of staphylococcal DNA was performed using the established procedures ${ }^{18,24}$. PFGE was prepared in a $1.2 \%$ agarose gel in a $1 \times \mathrm{TBE}$ buffer. Blocks containing restriction enzyme cleaved bacterial DNA were placed in prepared wells in the gel and covered with $0.8 \%$ low melting point agarose. PFGE was run at $5.0 \mathrm{~V} / \mathrm{cm}$ for $28 \mathrm{~h}$ at a pulse time of 0.1 to 30 seconds. The gel was subsequently stained with etidium bromide solution $(1 \mu \mathrm{g} / \mathrm{ml})$ and visualized.

\section{Scanning electron microscopy}

Test materials were placed in a fixation solution containing $2 \%$ glutaraldehyde, $1 \%$ formaldehyde, and $0.1 \mathrm{M}$ phosphate buffer at $\mathrm{pH} 7.2$ for two hours. This was followed by a standard SEM (scanning electron microscopy) sample preparation. A single operator $(\mathrm{RN})$ examined all preparations using the scanning electron microscope TESLA BS 340 (Czech Republic) under $3600 \times$, and $7000 \times$ magnification .

\section{RESULTS}

The results are presented in Table 2. Before and after the 7 day sterile preservation of the tested materials, the BHI broths containing material IV were visually clear and proved to be sterile after attempting bacterial cultivation on blood agar. The BHI broths containing samples I and II were visually cloudy before and after 7 day sterile preservation and subsequent incubation, and had staphylococcal concentrations higher than $1 \times 10^{6} \mathrm{cfu} / \mathrm{ml}$. BHI broths from samples I (UHMWPE) and II (Palamed ${ }^{\circledR}$ ) allowed staphylococcal growth to the above-mentioned concentrations after only $24 \mathrm{~h}$ of incubation. On sample 
Table 1. List of staphylococci used for testing.

\begin{tabular}{|c|l|l|c|c|c|c|}
\hline Strain & \multicolumn{1}{|c|}{ Species } & \multicolumn{1}{|c|}{ Source } & $\begin{array}{c}\text { Methicillin } \\
\text { S/R }\end{array}$ & $\begin{array}{c}\text { Gentamicin } \\
\text { S/R }\end{array}$ & $\begin{array}{c}\text { Vancomycin } \\
\text { S/R }\end{array}$ & $\begin{array}{c}\text { Biofilm } \\
\text { production }\end{array}$ \\
\hline 1 & Staphylococcus aureus & Blood; pt. with CRI & S & S & S & yes \\
\hline 2 & Staphylococcus aureus & Blood; pt. with CRI & R & R & S & yes \\
\hline 3 & Staphylococcus aureus & Septic TKA & S & S & S & yes \\
\hline 4 & Staphylococcus epidermidis & Blood; pt. with CRI & R & R & S & yes \\
\hline
\end{tabular}

$\mathrm{CRI}=$ catheter-related infection; TKA = total knee arthroplasty; $\mathrm{pt}$. = patient; $\mathrm{S}=$ susceptibility; $\mathrm{R}=$ resistance

Table 2. Growth of staphylococci in BHI broth with input orthopaedic material.

\begin{tabular}{|l|c|c|c|c|c|c|c|c|}
\hline \multirow{2}{*}{ Strain } & \multicolumn{2}{|c|}{1} & \multicolumn{2}{c|}{ 2 } & \multicolumn{2}{c|}{3} & \multicolumn{2}{c|}{ S. aureus } \\
\hline Time (hours) & $\mathbf{2 4}$ & $\mathbf{4 8}$ & $\mathbf{2 4}$ & $\mathbf{4 8}$ & $\mathbf{2 4}$ & $\mathbf{4 8}$ & $\mathbf{2 4}$ & $\mathbf{4 8}$ \\
\hline Material I & + & + & + & + & + & + & + & + \\
\hline Material II & + & + & + & + & + & + & + & + \\
\hline Material III & - & + & + & + & - & + & - & + \\
\hline Material IV & - & - & - & - & - & - & - & - \\
\hline
\end{tabular}

+ Growth of staphylococci; turbid $\left(1 \times 10^{6} \mathrm{cfu} / \mathrm{ml}\right)$

- Growth of staphylococci is inhibited; no turbidity

Table 3. Relative distribution of bacterial particles on the tested material surfaces.

\begin{tabular}{|l|c|c|c|c|c|c|c|c|}
\hline \multicolumn{1}{|c|}{ Strain } & \multicolumn{2}{|c|}{$\mathbf{1}$} & \multicolumn{2}{c|}{$\mathbf{2}$} & \multicolumn{2}{c|}{$\mathbf{3}$} & \multicolumn{2}{c|}{ S. epidermidis } \\
\hline Time (hours) & $\mathbf{2 4}$ & $\mathbf{4 8}$ & $\mathbf{2 4}$ & $\mathbf{4 8}$ & $\mathbf{2 4}$ & $\mathbf{4 8}$ & $\mathbf{2 4}$ & $\mathbf{4 8}$ \\
\hline Material I & ++ & ++ & ++ & ++ & ++ & ++ & ++ & ++ \\
\hline Material II & ++ & ++ & + & +++ & ++ & +++ & + & +++ \\
\hline Material III & + & + & + & + & + & + & + & + \\
\hline Material IV & - & - & - & - & - & - & - & - \\
\hline
\end{tabular}

- No bacterial particles observed in any fields

+ Less than 10 bacteria per field

++10 to 50 bacterial particles per field

+++ More than 50 bacterial particles per field

III (Palamed $\left.{ }^{\circledR} \mathrm{G}\right)$, only methicillin-resistant $S$. aureus (MRSA) strains reached $1 \times 10^{6} \mathrm{cfu} / \mathrm{ml}$ in $24 \mathrm{~h}$, in contrast to methicillin-sensitive $S$. aureus and $S$. epidermidis strains that required $48 \mathrm{~h}$ to achieve this concentration under the same conditions.

Seven days after removal of the biomaterials from the $\mathrm{BHI}$ broths and sterile preservation, reincubation in $\mathrm{BHI}$ broth for $48 \mathrm{~h}$ demonstrated similar findings. Staphylococcal identification after reincubation showed comparable microbial characteristics when evaluated against previous isolates from the respective orthopaedic materials with positive bacterial growth. Testing of minimal inhibitory concentrations (MIC) to antibiotics further confirmed this finding.

Retrospective identification and comparison of strains via DNA genome analysis was also used to identify and assess each staphylococcal isolate from the tested orthopaedic materials. PFGE demonstrated a very high probability that all retrieved staphylococci were identical to those initially inoculated on respective material formulations. 

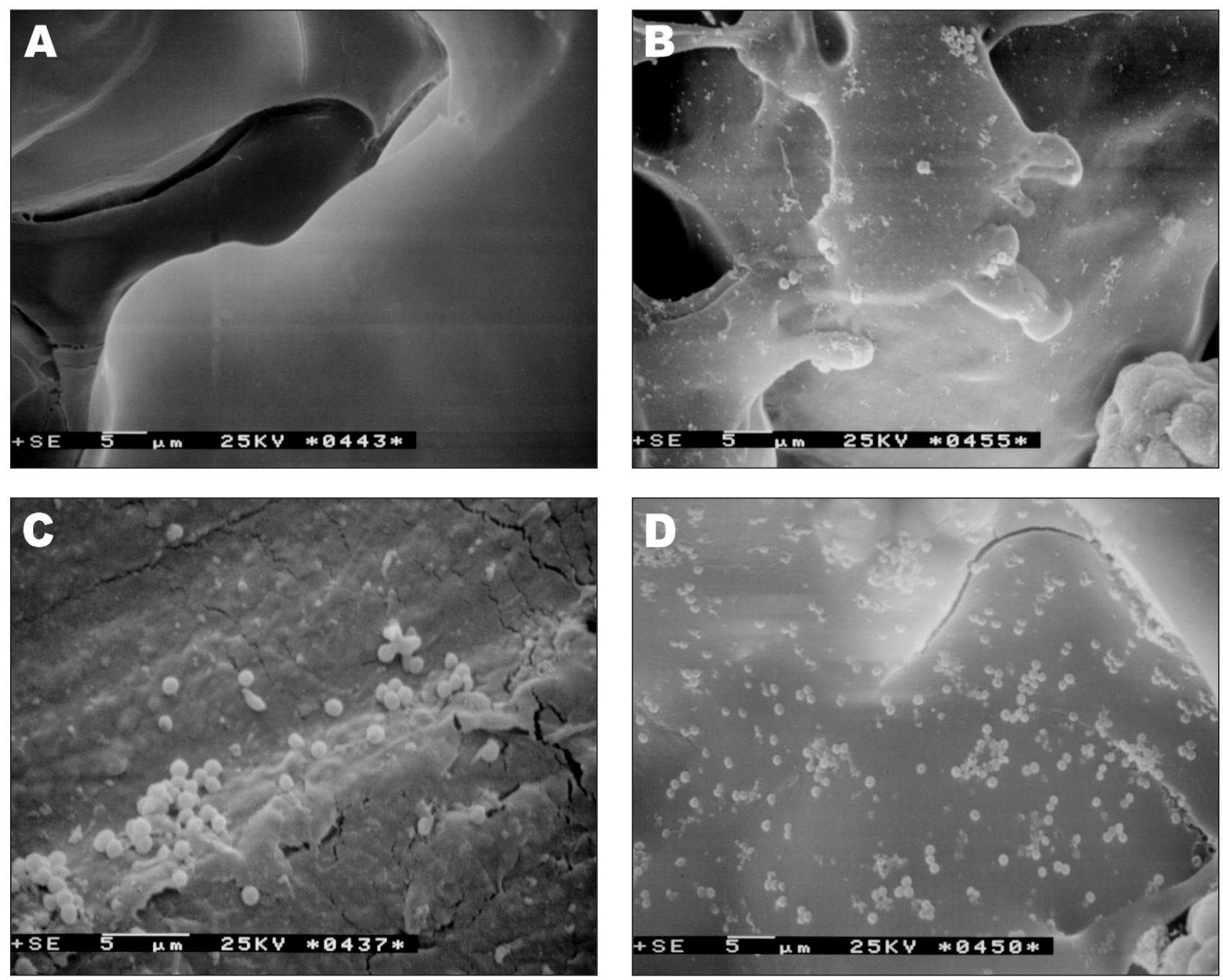

Fig. 1. A) Methicillin-resistant S. aureus on the surface of material No. IV (Genta/ Vanco loaded PMMA) after 24 hours. No bacterial particles seen at $3600 \times$ magnification.

B) S. aureus-2 on the surface of material No. III (PMMA with Gentamicin after 48 hours). Only single particles could be seen (relative amount + ; less than 10 bacteria per field) at $3600 \times$ magnification.

C) S. aureus- 1 on the polyethylene surface after 24 hours. Relative amount of bacterial particles was ++ (i. e. 10 to 50 bacterial particles per field) at $7000 \times$ magnification.

D) S. epidermidis-4 on the surface of material No. II (PMMA without antibiotic) after 48 hours. There is high concentration of bacterial particles on this surface (relative amounts $+++;>50$ bacterial particles per field) at $3600 \times$ magnification.

SEM showed that the material with gentamicin-vancomycin (IV sample) was effectively protected from bacterial colonization in contrast to the commercially manufactured PMMA and surfaces without antibiotic protection (Fig. 1). These results were also confirmed by semi-quantitative evaluation of each sample (Table 3 ).

\section{DISCUSSION}

The ability of coagulase-negative staphylococci to colonize indwelling medical devices has been recognized for some time ${ }^{26}$. It has been shown that key to preventing PJI is to avert bacterial adherence ${ }^{7}$. Measures directed towards this goal include a strict sterile operating room regime, precise surgical technique, patient standardization, local and systemic prophylactic antibiotic administration and others ${ }^{2}$. In general, if bacteria are able to defeat these measures and are given a window of opportunity to invade and establish themselves intraarticularly, PJI may develop or persist.

The exact mechanism by which antibiotics are released from bone cement is unknown to date. However, surface elution and diffusion have been suggested to explain the mechanism of antibiotic liberation from the loaded material $^{4,15,23}$. The amount of antibiotic eluted to the surroundings is a function of cement composition, porosity (the higher the better), total surface area exposed to fluid, as well as the concentration (low- versus high-dose) and characteristics of the antibiotic present in the cement ${ }^{15,23}$. The antibiotic release profile from bone cement is strongly time-dependent with rapid rise during the first $24 \mathrm{~h}$ (burst 
release) after which the concentration falls to suboptimal values $^{16}$. A vast number of antibiotics and cements have been tested under various conditions, but Palamed ${ }^{\circledR}$ and Palacos ${ }^{\circledR}$ bone cements seem to produce the best antibiotic release profiles among commercially available gentamicin-loaded cements ${ }^{10,19}$.

Our study demonstrated that gentamicin-vancomycin loaded PMMA effectively protected the cement surface and local environment from specific staphylococcal species. In comparison with Scott et al. ${ }^{20}$, we tested only a small number of staphylococcal strains and used different antibiotics (gentamicin and vancomycin versus tobramycin) as well as cement (Palamed ${ }^{\circledR} G$ versus Simplex P, Howmedica Inc.), but our results were similar. Oga et al. tested the effectiveness of Palacos ${ }^{\circledR}$ loaded with $1 \mathrm{~g}$ of tobramycin against $S$. epidermidis and found, via a plate count quantification technique and electron microscopy, an excellent protective effect on bacterial adhesion ${ }^{17}$. König et al. investigated $S$. epidermidis adhesion and accumulation on four different cements, including Palacos ${ }^{\circledR}$ (Merck, Germany) ${ }^{13}$. With the help of a bacterial adhesion assay and modified Kirby-Bauer technique, they concluded that gentamicin-clindamycin loaded bone cement (Genta-Clinda, Merck, Germany) gave the best protection against bacterial colonization.

Gentamicin-vancomycin loaded cements have also been widely evaluated ${ }^{4}$. Both antibiotics are active against most gram-positive organisms. However, gentamicin lacks complete coverage against one-third of MRSA isolates ${ }^{12}$, and according to our experience, can be totally ineffective. This possibly explains the observed growth of MRSA on the surfaces of commercially produced gentamicin bone cement in our study. The gentamicin "microbial gap" is further confirmed by Tunney et al. who tested several antibiotics in vitro against 49 bacterial isolates obtained from orthopaedic implants and found vancomycin and ciprofloxacin to have better coverage than gentamicin ${ }^{25}$.

There are several weaknesses in our study. First, the limited number of bacterial strains which were tested decreases the practical relevance of our results. Second, we must take into consideration that in vitro conditions do not precisely idealize the joint environment, since under in vivo conditions, diffusion gradients vary, and there is fluid flow that could significantly decrease the local antibiotic concentrations. Third, the risk for antibiotic loaded PMMA to induce vancomycin and other antibiotic resistant staphylococci was not investigated. Fourth, we did not examine the resulting mechanical strength of PMMA after incorporation of non-structural antibiotic molecules. However, in accordance with other authors ${ }^{3,5}$, we assume that the addition of $1 \mathrm{~g}$ of antibiotic powder insignificantly changes the intrinsic strength of PMMA.

Our study showed that low-dose gentamicin-vancomycin loaded bone cement had an excellent protective effect against staphylococcal colonization of PMMA surfaces in vitro. Although these findings cannot be immediately applied in practice, we do believe that the antibacterial and protective effects of low-dose gentamicin-vancomycin loaded PMMA and other antibiotic combinations warrant further investigation in vivo. From this point of view, it seems reasonable to use any empirically proven low-dose antibiotic combination as an additive to PMMA in highrisk PJI patients.

\section{ACKNOWLEDGEMENTS}

The authors wish to thank Ms. J. Potomková, Dr. L. Lu, PhD and A. Oulton for editorial work.

This paper was supported by grant IGA No. NM 7680-3

(Grant Agency of the Czech Ministry of Health).

\section{REFERENCES}

1. Performance standards for antimicrobial susceptibility testing. (2002) 12th informational supplement. Approved standard M100 - S12. In: Nat Comm Clin Lab Standards. Wayne, PA.

2. An YH, Friedman RJ. (1996) Prevention of sepsis in total joint arthroplasty. J Hosp Infect 33, 93-108.

3. Armstrong MS, Spencer RF, Cunningham JL, Gheduzzi S, Miles AW, Learmonth ID. (2002) Mechanical characteristics of antibiotic-laden bone cement. Acta Orthop Scand 73, 688-90.

4. Bertazzoni Minelli E, Benini A, Magnan B, Bartolozzi P. (2004) Release of gentamicin and vancomycin from temporary human hip spacers in two-stage revision of infected arthroplasty. J Antimicrob Chemother 53, 329-34.

5. Bourne RB. (2004) Prophylactic use of antibiotic bone cement. An emerging standard-in the affirmative. J Arthroplasty 19 (Suppl.1), 69-72.

6. Critchley I, Karginova EA, Thornsberry C, et al. (2002) Prevalence of biofilm (BF) production in recent clinical isolates of Staphylococcus aureus (SA), Staphylococcus epidermidis (SE), and Pseudomonas aeruginosa (PA). In: 42nd interscience conference on antimicrobial agents and chemotherapy. Program and abstracts. Abstract No.B-269.

7. Gristina AG, Costerton JW. (1985) Bacterial adherence to biomaterials and tissue. The significance of its role in clinical sepsis. J Bone Joint Surg 67A, 264-73.

8. Gristina AG, Naylor PT, Webb LX. (1990) Molecular mechanism in musculoskeletal sepsis: The race for the surface. Instr Course Lect (AAOS) 39, 471-86.

9. Harris WH. (2004) Conquest of a worldwide human disease: particle-induced periprosthetic osteolysis. Clin Orthop 429, 39-42.

10. Hendriks JGE, Neut D, van Horn JR, van der Mei HC, Busscher HJ. (2003) The release of gentamicin from acrylic bone cements in a simulated prosthesis-related interfacial gap. J Biomed Mater Res Part B: Appl Biomater 64B, 1-5.

11. Jahoda D, Sosna A, Landor I, Vavř́ik P, Pokorný D, Hudec T. (2003) Two-stage reimplantation using spacers-the method of choice in treatment of hip joint prosthesis-related infections. Comparison with methods used from 1979 to 1998. Acta Chir Orthop Traumatol Cech 70, 17-24.

12. Jones ME, Karlowsky JA, Draghi DC, Thornsberry C, Sahm DF, Nathwani D. (2004) Antibiotic susceptibility of bacteria most commonly isolated from bone related infections: the role of cephalosporins in antimicrobial therapy. Int J Antimicrob Agents 23, 240-46.

13. Konig DP, Schierholz JM, Hilgers R-D, Bertram C, Perdreau-Remington F, Rütt J. (2001) In vitro adherence and accumulation of staphylococcus epidermidis RP-62A and staphylococcus epidermidis M7 on four different bone cements. Langenbeck's Arch Surg 386, 328-32.

14. Krbec M, Čech O, Džupa V, Pacovský V, Klezl Z. (2004) Infection complications of total hip arthroplasty. Acta Chir Orthop Traumatol Cech 71, 179-88. 
15. Neut D, van de Belt H, van Horn JR, van der Mei HC, Busscher HJ. (2003) Residual gentamicin-release from antibiotic-loaded polymethylmethacrylate beads after 5 years of implantation. Biomaterials 24, 1829-31.

16. Neut $D$, van de Belt $H$, van Horn JR, van der Mei HC, Busscher HJ. (2003) The effect of mixing on gentamicin release from polymethylmethacrylate bone cements. Acta Orthop Scand 74, 670-6.

17. Oga M, Arizono T, Sugioka Y, Naylor PT, Myrvik QN, Gristina AG. (1992) The inhibition of bacterial adhesion to a tobramycinimpregnated polymethylmethacrylate substratum. J Long Term Eff Med Implants 1, 321-8.

18. Pantůček R, Götz F, Doškáŕ J, Rosypal S. (1996) Genomic variability of Staphylococcus aureus and the other coagulase-positive Staphylococcus species estimated by macrorestriction analysis using pulsed-field gel electrophoresis. International Journal of Systematic Bacteriology 46, 216-22.

19. Penner MJ, Duncan CP, Masri BA. (1999) The in vitro elution characteristics of antibiotic-loaded CMW and Palacos R bone cements. J Arthroplasty 14, 209-14.

20. Scott CP, Higham PA, Dumbleton JH. (1999) Effectiveness of bone cement containing tobramycin. J Bone Joint Surg 81B, 440-3.

21. Schmalzried TP, Amstutz HC, Au MK, Dorey FJ. (1992) Etiology of deep sepsis in total hip arthroplasty. The significance of hematogenous and recurrent infections. Clin Orthop 280, 200-7.
22. Steckelberg JM, Osmon DR. (2000) Prosthetic joint infections. In: Infections associated with indwelling medical devices. Edited by Waldvogel FA, Bisno AL. Washington, ASM Press, 173-79.

23. Sterling GJ, Crawford S, Potter JH, Koerbin G, Crawford R. (2003) The pharmacokinetics of simplex-tobramycin bone cement. J Bone Joint Surg 85B, 646-9.

24. Tenover FC, Arbeit RD, Goering RV, Mickelson PA, Murray BE, Persing DH, Swaminathan B. (1995) Interpreting chromosomal DNA restriction patterns produced by pulsed-field gel electrophoresis: criteria for bacterial strain typing. J Clin Microbiol 33, 2233-9.

25. Tunney MM, Ramage G, Patrick S, Nixon JR, Murphy PG, Gorman SP. (1998) Antimicrobial susceptibility of bacteria isolated from orthopedic implants following revision surgery. Antimicrob Agents Chemother 42, 3002-5.

26. von Eiff C, Peters G, Heilmann C. (2002) Pathogenesis of infections due to coagulase-negative staphylococci. Lancet Infect Dis 2, 677-85.

27. Wahlig H, Dingeldein E. (1980) Antibiotics and bone cements Experimental and clinical long-term observations. Acta Orthop Scand 51, 49-56.

28. Wright RJ, Sledge CB, Poss R, Ewald FC, Walsh ME, Lingard EA. (2004) Patient-reported outcome and survivorship after Kinemax total knee arthroplasty. J Bone Joint Surg 86A, 2464-70. 